Aman is published twice a year, and the annual subscription is $\mathbb{6} 6.00$. Enquiries and subscriptions to:

\author{
The Editor-in-Chief, \\ Aman, \\ Centre for Social, Cultural and \\ Environmental Research, \\ University of Benin, \\ P.M.B. 1154, \\ Benin City, \\ Bendel State, \\ Nigeria.
}

\title{
Africana Directions
}

The Information Office of the Library of Congress, Washington D.C., announces Africana Directions, a new series of guides prepared by the African Section of the Library of Congress. To be issued irregularly, they will consist of brief bibliographies, reading lists or reference aids on topics of current interest. Africana Directions will not only be of value to visitors to the Library's African Section, but will also serve the needs of other scholars and librarians interested in the dynamic political, economic, or social environment of sub-Saharan Africa.

The first issue in the new series, an especially topical bibliography, is a fourteen-page list of references entitled Recent Afro-Libyan Relations compiled by Joanne $M$. Zellers. It includes one hundred and five entries and a map. Future issues in the series will generally not exceed ten pages in length. Titles in the series will be numbered sequentially by year. Recent Afro-Libyan Relations is AD 81-1.

This issue of Africana Directions concerns Afro-Libyan relations since 1976 and West African reactions to Libyan involvement in Chad. Compiled from Western language sources, the list is divided into three main sections: recent sources on Afro-Arab relations; general Afro-Libyan relations since 1976; and Libyan relations with selected African countries. Catalogued works are identified by call numbers and uncatalogued material by the symbol DLC. A map of Africa is included for reference.

Copies of Recent Afro-Libyan Relations and future issues in this series are available free of charge from:

The Library of Congress,

African and Middle Eastern Division,

African Section,

Washington, D.C. 20540.

The Britain-Zimbabwe Society

Friendship societies between Britain and other countries are legion; the Britain-Zimbabwe Society, inaugurated at a public meeting at the Africa Centre, Covent Garden, on 29 October 1981, is unusual in that most of its initial membership was drawn not from retired diplomats or ex-colonial officers but from the ranks of those people who consistently advocated the principle of 'No independence before 
majority rule'. The Society seeks to bring the peoples of Britain and Zimbabwe, as individuals, to understand and respect each other in a way which was not possible in the past. The Prime Minister of Zimbabwe personally supports the establishment of the Society, but it has no official connection with any government. Membership is open to anyone, and its Constitution seeks to ensure that it will be the membership which decides the policy of the Society.

The principal activities of the Society seek to foster an informed understanding in Britain and elsewhere of developments in Zimbabwe. It circulates regularly a bulletin, independently produced by the Zimbabwe Project in Salisbury, with reports on economic, political and social developments. A flourishing branch in Manchester is already active and other branches are being formed elsewhere. The Society hopes to encourage contacts with Zimbabwean students and residents in the $\mathrm{UK}$, and to promote discount fare schemes for members travelling to and from Zimbabwe. It is hoped that a section of the Society will be formed in Zimbabwe.

At the inaugural meeting, Mr Guy Clutton-Brock was elected President of the Society. The following officers were elected: Chairman, Professor Richard Gray; Vice-Chairman, Professor Terence Ranger; Secretary, Mrs Rosamund Henriques; Associate Secretary, Mr Percy B. Murombe-Chivero; Treasurer, Mr Christopher Paterson.

Subscriptions are as follows:

Ordinary individual members

Joint membership (spouses)

Unwaged (students, pensioners)

Further information is available from:

The Secretary,

Britain-Zimbabwe Society,

38 King Street,

London WC2E 8JS 